\title{
IMPLEMENTATION OF WATER SAFETY PLANS IN BANGLADESH: SITUATION AND NEED ANALYSIS
}

\author{
M M Rahman* and C K Paul
}

\begin{abstract}
Water safety plans (WSPs) is a comprehensive health-based risk assessment and risk management approach to optimizing drinking-water safely from catchments to consumer. The focus of this research is the development and implementation of water safety plans (WSPs) to be used by the water supplier. The study was conducted at 13 districts and 18 upazills (rural and urban) among the whole Bangladesh. The data were collected during March to May, 2008 to conduct the study. In the study, primary data were collected directly from the respondents while secondary data were collected from different records available at different office, internet and journals. It was found that deep tube well and shallow tube well water was used for drinking purposes by $31.43 \%$ and $24.29 \%$ respondents respectively where as minority of the respondents used other sources. Perception about the safe drinking water for the respondents was found mostly $63 \%$ among all the respondents followed by moderately safe $21 \%$. About $54.29 \%$ respondents were found to be fully satisfied about their drinking water followed by moderately satisfied $30 \%$. Among all the beneficiaries $82.86 \%$ beneficiaries have been indicated communication materials like booklet, leaflet, poster, manuals, etc was available. This investigation found that $83.33 \%$ rain water harvesting plant and $66.67 \%$ deep tube well water source were in high risk category. The chances of contamination were high in the period of covering the water vessels during storage of water $64.71 \%$. About $88.10 \%$ respondents among all the official respondents received the water safety plans training. About $66.67 \%$ officials have been responded that no sanitary inspection was done. Most of the respondents $(78.57 \%$ beneficiaries and $76.19 \%$ organizational personnel) had high perception about the selected benefits of water safety plans. Among all the officials and beneficiaries i.e. $66.67 \%$ organizational personnel and $75.71 \%$ beneficiaries had high perception in selected limitations to implement the water safety plans. Finally $95.24 \%$ organizational personnel and $81.43 \%$ beneficiaries had high perception about the selected necessities to successful implementation of water safety plans in Bangladesh.
\end{abstract}

Keywords: Water, Safety, Plan, Situation, Need, Analysis, Bangladesh

\section{INTRODUCTION}

The process of implementation of water safety plans (WSPs) in Bangladesh with the benefits, limitations and further needs to successful implementation focus of attention has been on rural water supplies, although there has also been some experience with pourshava piped water supplies. The water supply sector in Bangladesh has taken this up and the major rural and small town water supply programmes have made commitments to implement water safety plans in their future programmes. In order for WSPs to be utilized effectively in Bangladesh, the general guidance available from WHO

\footnotetext{
* Corresponding author: Dr. Md. Mujibor Rahman, Associate Professor, Environmental Science Discipline, Khulna University, Khulna 9208, Bangladesh, E-mail: mujibku@gmail.com, Mobile: 01676109008.
} 
(WHO, 2004; Davison et al., 2005) needed to be modified to reflect local conditions. This study consolidates the experience of the development of 'model' WSPs for key rural water supply technologies and of implementing WSPs in communities by NGOs and the Department of Public Health Engineering (DPHE). Three NGOs and DPHE undertook pilot projects to implement WSPs in a number of areas in Bangladesh and for a variety of technologies. In addition, the DPHE-UNICEF arsenic project has also implemented WSPs in a further 23 Upazilas. The model WSPs and community monitoring tools were developed to ensure these were appropriate to local conditions. This experience provides the sector with an understanding as to how WSPs can be replicated at scale and the modifications that may be required for scaling up. The results and experience gained from the study will help planners, implementers and policy makers in understanding the importance of WSPs and the process steps required to implement WSPs in field conditions. It is also expected that they will also be able to realize the real benefits and the challenges of WSPs and to identify the areas where emphasis should be given. The most effective means of consistently ensuring the safety of drinking-water supply is through the use of a comprehensive risk assessment and risk management approach that encompasses all steps in water supply from catchments to consumers. In these guide lines, such approaches are termed water safety plans (WSPs). The WSP approach has been developed to organize and systematize a long history of management practices applied to drinking water and to ensure the applicability of the practices to the management of drinking water quality ('Managing drinking-water quality from catchments to consumer', WHO,2005). According to World Health Organization (WHO) the primary objectives of a WSP in ensuring good drinking water supply practice are: (i) the minimization of contamination of source water, (ii) the reduction or removal of contamination through treatment processes, and (iii) the prevention of contamination drinking storage, distribution and handling of drinking water ('Managing drinking-water quality from catchments to consumer', WHO, 2005). The WSP has three key components and overseen through drinking-water supply surveillance as follows: (i) a system assessment, (ii) effective operational monitoring; and (iii) management plans. The use of water safety plans should greatly enhance the confidence of policy makers and sector stakeholders that the target has genuinely been achieved and contributes to the improved public health and reduced poverty. Furthermore, the right to water (UN 2003), places a clear responsibility on Governments to ensure access to safe and adequate water supplies. Although better health protection is reason in its own right for the adoption of strategies to improve drinking-water quality, international policy is also a key factor. Water suppliers have a duty of care to persons utilizing the water or service that they supply and therefore, need to be aware of the regulatory and policy framework within which they must operate including common law (where appropriate), statute, policy, guidelines and best management practice. An iterative cycle that encompasses assessment of public health concerns, risk assessment, the establishment of health-based targets and risk management. Feeding into this cycle is the determination of environmental exposure and the estimation of what constitutes a tolerable (or acceptable) risk (Ahmed and Rahman 2000). Supply of safe drinking water has been one of the main agenda of civilizations and continuing through the MDGs. But most of the populations in the developing countries and other stressed areas, irrespective of the access of improved and not-improved technological options, have been exposed to the risks of drinking biologically and/or chemically contaminated water at the consumption point. The objectives clearly calls upon a few systems linked 
into one WSP system including various types and levels of timely actions by multiple actors within the sub-systems as well as the WSP system. The Arsenic Policy Support Unit (APSU, 2005) of the Ministry of Local Government Rend Development \& Cooperatives with substantial support from DFID and other external/international partners; facilitated the introduction and initial development of WSP. It also supported pilot testing of the 'Model' WSPs and its further development at the community levels in collaboration with ITN-BUET. Dhaka Community Hospital, DPHE-UNICEF Arsenic Mitigation Project, Environment and Population Research Centre (EPRC) and NGO Forum implemented the pilot projects for Drinking Water Supply and Sanitation. The results of the pilot projects were positive and the success of a diverse range of organizations in implementing WSPs provided confidence that their use can be scaled up. It was also reported that although the bacteriological contamination reduced significantly after incorporation of WSP; the risks from the existing concentrations of the bacteriological and/or chemical contaminations as well as from the bacteriological recontamination remained at considerable to high level depending on the technological, social, environmental and other variables (Fewtrell and Bartram, 2001). The Department of Public Health Engineering (DPHE) incorporated WSP in the "Water Quality Monitoring and Surveillance Protocol for Removal Water Supply System in Bangladesh'” in 2005. It has provided by suggestions related to WSP implementation and focused all drinking water sources. Currently WSP is being promoted by DPHE in a limited scale, implemented by a major drinking water development partner

(Water-AID Bangladesh; WAB) in several sub-districts through NGOs, and researched/piloted at a minimum level by a few organizations like WHO, UNICEF, JICA, and Environment and Population Research Centre (EPRC). Overall, some level of WSP activities is ongoing in approximately 24\% districts and in only about $9 \%$ sub-districts. But the country is faced with severe challenge of safe drinking water.

\section{WATER SAFETY PLAN}

A comprehensive health-based risk assessment and risk management approach to optimizing drinkingwater safely from catchments to consumer. The objectives of a water safety plan are to ensure safe drinking-water through good water supply practice, that is: (I) To prevent contamination of source waters; (II) To treat the water to reduce or remove contamination that could be present to the extent necessary to meet the water quality targets; and (III) To prevent re-contamination during storage, distribution and handling of drinking-water. 
The focus of this document is the development and implementation of water safety plans to be used by the water supplier.

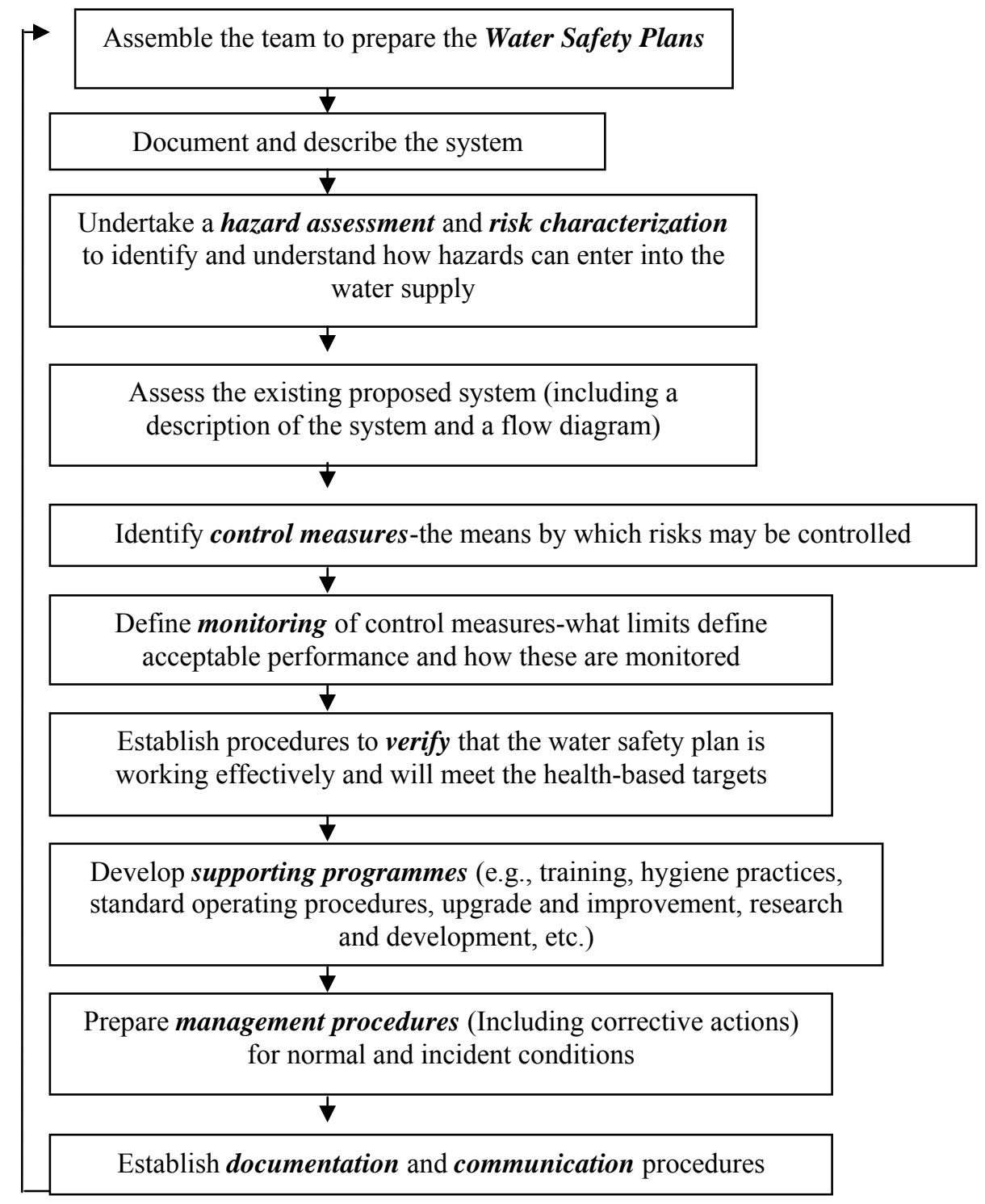

Figure 1 Overview of the key steps in developing a water safety plans (adapted from WHO, 2004).

\section{The basis for water safety}

The most cost-effective and protective means of consistently assuring a supply of acceptable drinkingwater is the application of some form of risk management based on sound science and supported by appropriate monitoring. It is important that risk management is inclusive and, therefore, needs to cover the whole system from catchments to consumer. 


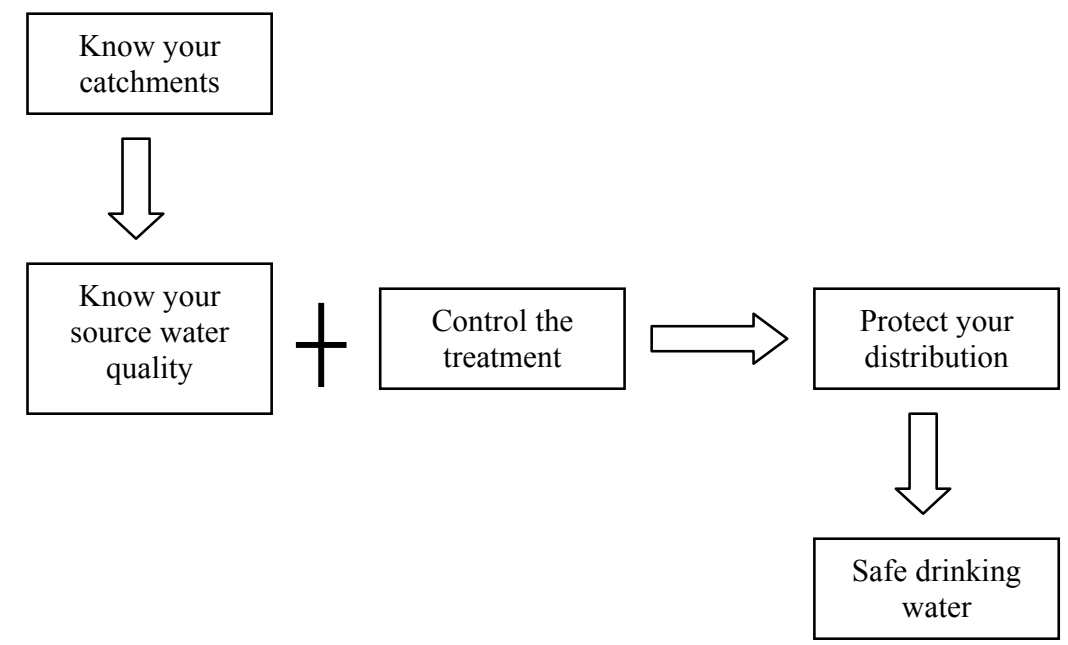

Figure 2 'Catchments to consumer' approach to risk management of the safety of drinking water (Mahmud et al. 2007).

The risk management approach that was outlined based largely upon HACCP (Hazard Analysis and Critical Control Point). The principles of HACCP (which is a preventive risk management system that has been used in the food manufacturing industry for a number of decades) are based on developing an understanding of the system, prioritizing risks and ensuring that appropriate control measures are in place to reduce risks to an acceptable level. These principles have been refined and tailored to the context of drinking-water following the application of HACCP by several water utilities including in the US and Australia (Deere and Davison 1998; Gray and Morain 2000; Deere et al. 2001). The experience of the application of HACCP by water utilities has informed the development of the water safety plan approach.

\section{Current management approaches}

There is a wide range of both chemical and microbial contaminants that may be found in drinkingwater, some of which can have adverse health effects on consumers. These can be derived from a number of sources including, in some instances, the water treatment process. Understanding the nature of sources of contamination and how these may enter the water supply is critical for assuring water safety. For instance, arsenic has become a major international concern in groundwater where it occurs from a geological source and it is primarily controlled through source selection.

Water supply systems can be considered as a number of steps aimed at assuring the safety of drinkingwater, including:

- preventing pollution of source waters;

- Selective water harvesting;

- controlled storage;

- Treatment prior to distribution;

- Protection during distribution; and

- Safe storage within the home and, in some circumstances, treatment at the point of use.

These steps can function as barriers, where activities are designed to minimize the likelihood of contaminants entering the water supply or reduce or eliminate contaminants already present in the supply. With the multiple barrier approach, each barrier provides an incremental reduction in the risk 
of water becoming unsafe. If there is a failure at one point, the other barriers continue to provide protection.

An important strategy in providing safe drinking-water for the consumer is the multiple barrier approach (Teunis et al. in preparation) the application of which is often restricted to the actual water treatment process. As the detection and enumeration of pathogenic microorganisms from microbial contaminated water is both difficult and costly reliance has traditionally been placed on the examination for microbial indicators of pollution (Davison et al. 2005). These indicators are usually non-pathogenic bacteria, which are present in faecal material in large amounts. Their numeration is relatively easy and inexpensive (in comparison with that for individual pathogens). Microbial contaminants, however, are not limited to bacteria and illness may result from exposure to pathogenic viruses or protozoa, both of which have different environmental behavior and survival characteristics to bacteria. This, coupled with the fact that testing of water immediately prior to, or within, distribution (end product testing) can only highlight a potential health problem after the water has been consumed, has led to the recognition of the need to adopt additional approaches to assuring water quality and safety.

\section{Framework for safe drinking-water and water safety plans}

The Guidelines for Drinking-water Quality WHO (2004) outlines, a preventive management framework for safe drinking-water that comprises five components (summarized in Figure 3), three of which combine to form the water safety plan such as (I) Health based targets (based on an evaluation of health concerns); (II) System assessment (to determine whether the water supply chain (from source through treatment to the point of consumption) as a whole can deliver water of a quality that meets the health-based targets; (III) Operational monitoring of the control measures in the supply chain, which are of particular importance in securing drinking-water safety; (IV) Management plans (documenting the system assessment and monitoring; describing actions to be taken in normal operation and incident conditions - including upgrade and improvement), documentation and communication;(V) A system of independent surveillance that verifies that the above are operating properly.

A water safety plan, therefore, comprises system assessment and design, operational monitoring and management plans (including documentation and communication).

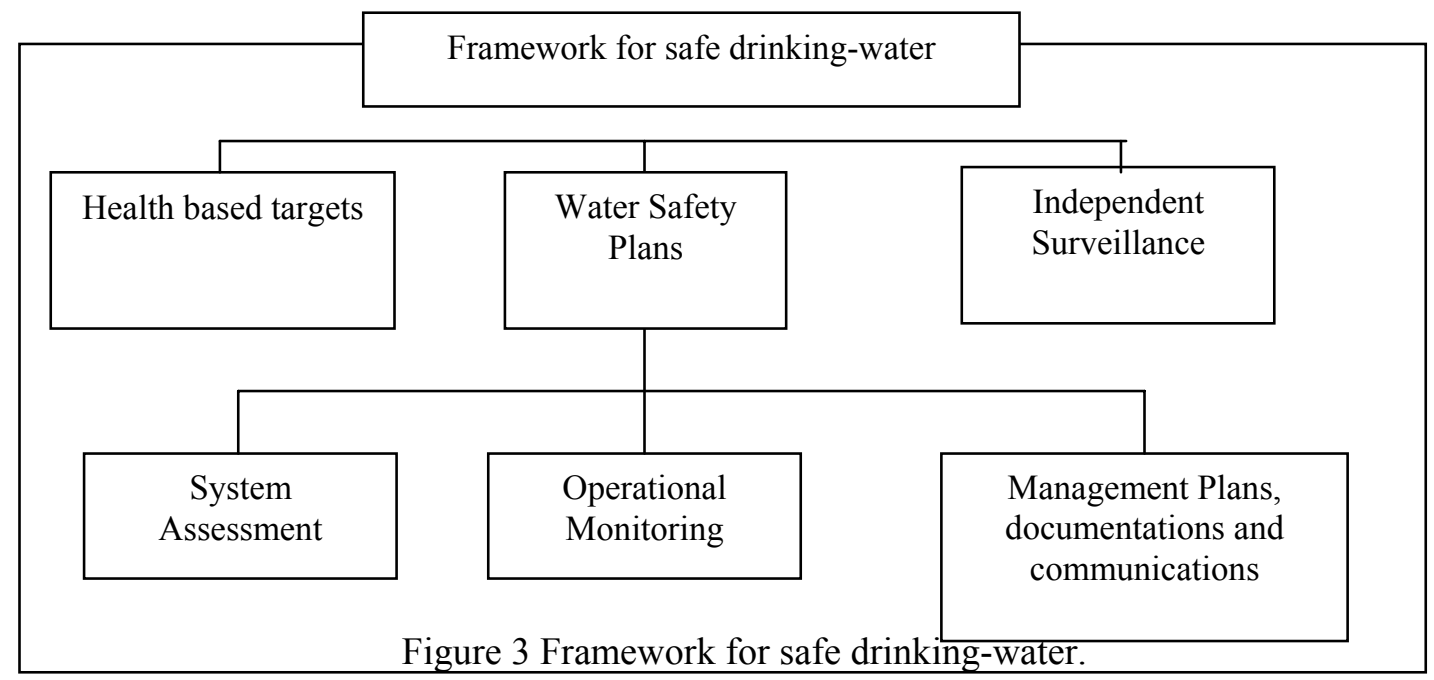




\section{Objectives}

The study was conducted to fulfill the following objectives:

i) to assess the present situation of water safety plans implementation;

ii) to identify benefits and limitations to implement water safety plans; and

iii) to assess the necessities for the development of water safety plans implementation.

\section{METHODOLOGY}

The respondents' perceptions were tested on the basis of analysis of selected 3 benefits. In this session the respondents' perception are analyzed for interpretation and understanding chronologically. Firstly, the distribution of the respondents was done based on their perception against each of the 3 statements i.e., the benefits as well as the overall perception regarding the benefits to implement water safety plans. It is very difficult to determine the perception of an individual regarding anything because perception varies from individual to individual. Same thing could be perceived differently/different ways by different individual. However, the respondents were asked to express their perception by indicating agreement against each of the selected 3 statements related to benefits to implement water safety plans and based on the agreements (opinions), the respondents were distributed in different agreement categories. The study area is important for any kind of research. The study was conducted at 13 districts and 18 upazillas (rural and urban) all over the country. Map of the study area into the map of the Bangladesh is shown in map 1.

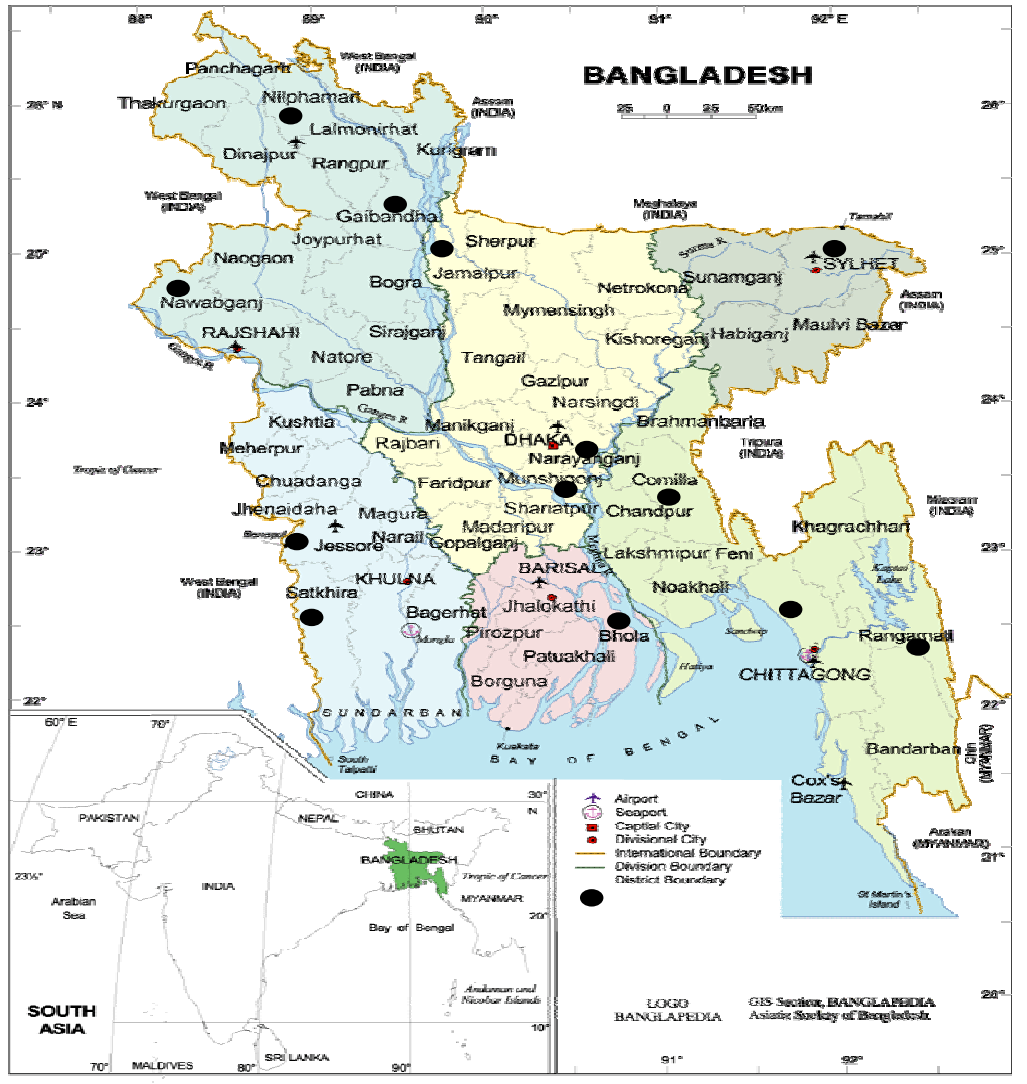

Map 1: Selected study area of Bangladesh. 


\section{RESULTS AND DISCUSSION}

The study investigated the present situation of water safety plans (WSPs), the difficulties, barriers and obstacles to implement WSP. Behavior of an individual is largely determined by his characteristics. These characteristics were age, gender, family size, and area type.

\section{Age}

The age of the respondents range from 30-45 with an average of 36.97 years (Table 1). The respondents were classified into three categories as shown in the Table 1. This classification has the agreement with Ahmed (2003). Most of the respondents were young (upto 35 years) and the rest were older medium ( $36-50$ years).

Table 1 Facts on age, gender and are a type profile of the respondents.

\begin{tabular}{|c|c|c|c|c|c|}
\hline Characteristics & Categories (Scores) & $\begin{array}{ll}\text { Number } & \text { of } \\
\text { respondents }\end{array}$ & $\begin{array}{l}\text { Distribution of } \\
\text { respondents (\%) }\end{array}$ & Range & Mean \\
\hline \multirow[t]{4}{*}{ Age } & Young ( Upto35 years) & 39 & 55.41 & \multirow{3}{*}{$30-45$} & \multirow{3}{*}{36.97} \\
\hline & Medium $(36-50$ years $)$ & 32 & 44.29 & & \\
\hline & Old $(>50$ years) & 0 & 0 & & \\
\hline & Total & 70 & 100 & & \\
\hline \multirow[t]{3}{*}{ Gender } & Male & 37 & 52.88 & & \\
\hline & Female & 33 & 47.12 & & \\
\hline & Total & 70 & 100 & & \\
\hline \multirow[t]{2}{*}{ Area type } & Rural & 48 & 69 & & \\
\hline & Urban & 22 & 31 & & \\
\hline
\end{tabular}

\section{Gender}

Among all the respondents, $52.88 \%$ were male and $47.12 \%$ were female (Table 1) that is near about half of the total respondents were female. Women are directly engaged in water related household works in Bangladesh that's why to complete the study effectively about 50\% women were interviewed among all the respondents.

\section{Family size}

The family size of the respondents ranged from 4-9 with an average of 5.84. Majority (40\%) of the respondents was in the medium group (5-6 family members) followed by small group (upto 4 family members) $31 \%$ and large ( $>6$ family members) $29 \%$.After conducting a study, Begum (2004) reported that the size of the family was observed as 4.59 persons where nearly half of the respondents (48\%) having less than five members. Age of the respondent, number of children, age of the first and last child, average monthly income, number of rooms in the house, persons living in the main dwelling houses, number of earning persons having audio-visual assets had statistically significant association with the size of the family. But in the study area, as most of the respondents had been found to have medium family because of their age of the respondents, their educational status, socio-economic condition of the respondents. Moreover, majority of the respondents were observed not to be fond of 
joint family though in some cases, it was found that they were moderately conscious about family size and population growth.

\section{Area type}

Respondents were classified into 2 categories on the basis of their dwelling place. In the study area, $69 \%$ respondents were found to live in the rural area where as the rest $31 \%$ respondents were in urban. The result indicated that most of the water safety plan projects were implemented in the rural areas because education and awareness level of the rural people about the safe water were low compared to the urban inhabitants that's why the study represents mostly the rural area.

\section{Water related issues}

Water related different factors such as sources of water to use, their taste, availability, arsenic condition, and the user's satisfaction level are important to categories for the interpretation of the different components of the water safety plans and its present situation.

\section{Source of water to use}

Deep tube well, shallow tube well, pond sand filter, rain water harvesting, dug well, pipe water were the different sources of water/ all cases of drinking, cooking and bathing. In case of drinking, it was found in the study area that deep tube well and shallow tube well water was used by $31.43 \%$ and $24.29 \%$ respondents where as minority of the respondents use other sources. None was found to use pond water for drinking purposes (Figure 4). On the other hand, 54.29\% respondents used shallow tube well water and $28.57 \%$ respondents used pond water for their cooking. Beside these, $54.29 \%$ of the respondents used the pond water for their bathing purpose followed by $28.57 \%$ deep tube well water and $25.71 \%$ shallow tube well water respectively (Figure 4 ). None was found to use pond sand filter and rain water harvesting for their bathing.

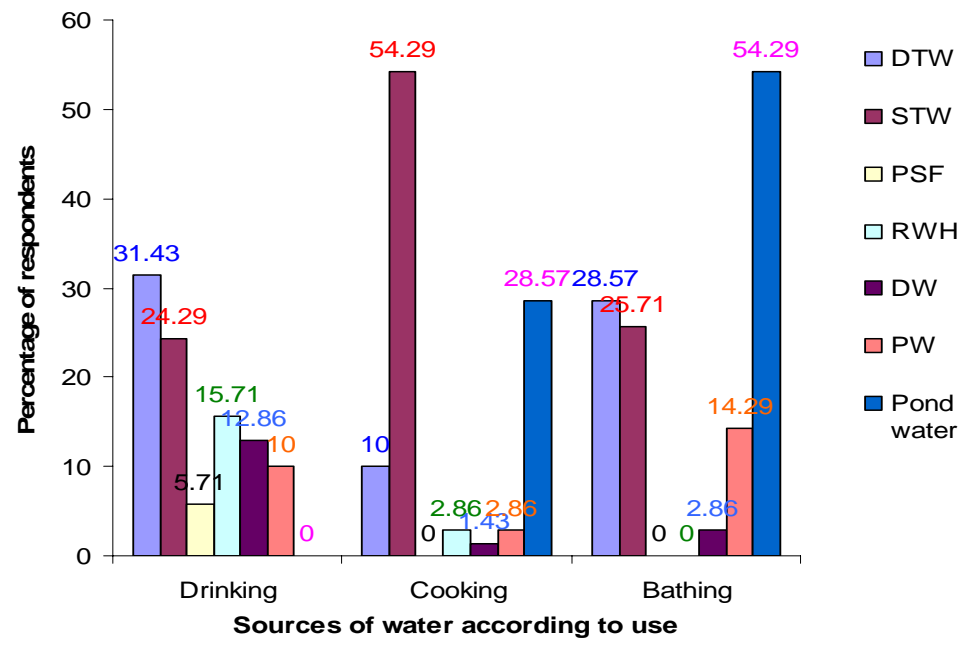

Note: DTW= Deep tube well, STW= Shallow Tube well, PSF= pond Sand Filter, RWH= Rain Water Harvesting, DW= Dug well, PW= Pipe water.

Figure 4. Different sources of water. 
In Bangladesh most of the drinking water sources were DTW. Beside this the study indicated that STW, RWH and pipe water supply were increasing day by day after the WSP project implementation. No one use the pond water for their drinking purposed mentioned the awareness rising about the water safety.

\section{Establishment of water source}

Among all the respondents, $60 \%$ of the respondents indicated that majority of the water options were established by the NGOs in their area followed by government establishment of water (30\%). Normally majority of the water option was established by the government but in this study it was found NGOs as because Water Safety plans were engaged all sorts of the study. So different NGOs were implemented water safety plan project only newly established water options. In the study, drinking water sources were mostly established by the NGOs rather than government as because the study area were the WSP project implemented area where different alternative sources were existed like pond sand filter, rain water harvesting, dug well, shallow tube. This result did not show at the total drinking water source established in Bangladesh performed Bangladeshi government greater than NGOs.

\section{Arsenic condition}

About $58.58 \%$ of the respondents responded that their drinking water source was totally arsenic free where as 30\% responded that they did not know (Table 2). In Bangladesh both of government and NGOs organizations were so much aware about the arsenic but in my study showed that about $30 \%$ respondent don't know as because lack of educational condition of the people in the study area and also indicated that after the implementation of WSP project no change showed at the awareness rising level.

Table 2. Arsenic condition in the study area.

\begin{tabular}{|c|l|c|c|}
\hline Characteristics & Categories (Scores) & $\begin{array}{c}\text { Number of } \\
\text { respondents }\end{array}$ & $\begin{array}{c}\text { Distribution of } \\
\text { respondents (\%) }\end{array}$ \\
\hline Arsenic condition & Arsenic positive & 8 & 11.43 \\
\cline { 2 - 4 } & Arsenic free & 41 & 58.58 \\
\cline { 2 - 4 } & Don't know & 21 & 30 \\
\hline
\end{tabular}

\section{Taste of drinking water}

About $50 \%$ respondents responded that their drinking water taste was good without any consideration but rest of the respondents indicated moderate, odor and iron as $17.14 \%, 12.86 \%$ and $11.43 \%$ respectively. The investigation about this category describes the ignorance of the importance of water quality among the total respondents as because none was found to say bad of water taste.

In the present situation it is not possible that no drinking water is bad. So the result indicated that the total ignorance of the people about the water quality and also indicated that the education about the diseases transmission route was not clear to the beneficiaries.

\section{Availability of drinking water}

In this study, most of the respondents (about 60\%) were found to say that their water availability was good where as different organization said, it was $69.05 \%$. About $32.86 \%$ of the total beneficiaries and 
$21.43 \%$ respondents of the officials responded moderate availability of water around their area. Both official and beneficiaries responded as bad and they were $9.52 \%$ and $7.14 \%$ respectively (Figure 5). This study conducted mostly in rural areas rather than urban area. This is why most of the respondents responded water availability was good. In the urban areas it was not same but they had some alternative sources of drinking water.

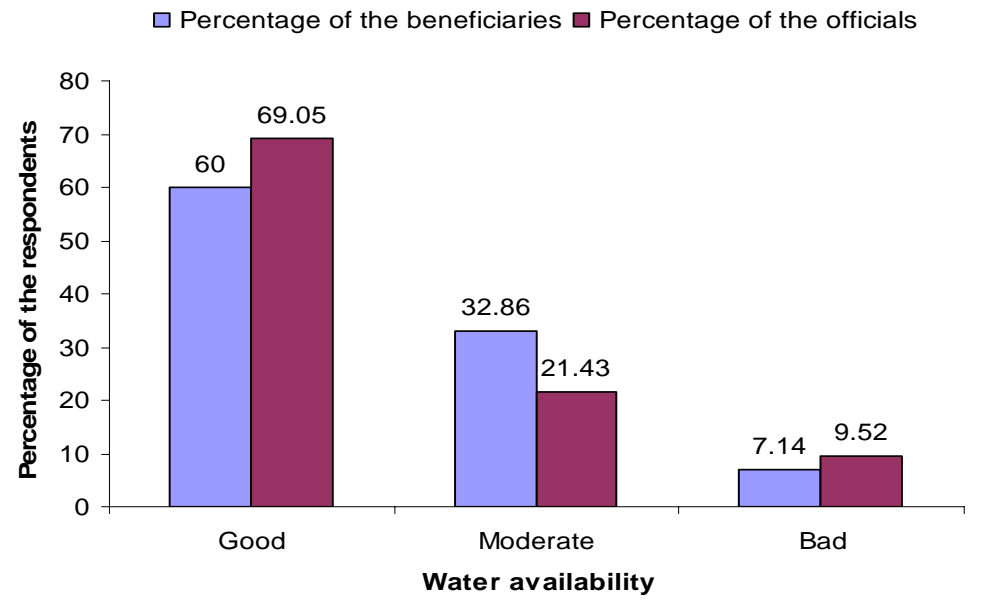

Figure 5 Availability of water in the study area.

\section{Safeness of drinking water}

Perception about the drinking water which is safe for the respondents was found mostly $63 \%$ among all the respondents followed by moderately safe $21 \%$. In this study $9 \%$ of the respondents indicated that they did not know about the water safety (Figure 6). In the study area, it was mostly found that whole the year children, women were in diarrheal and skin diseases although they responded most of the drinking water sources are safe. Compared with the sanitary inspection these results indicated the total ignorance and lack of knowledge about the safe drinking water and the spread of water related diseases.

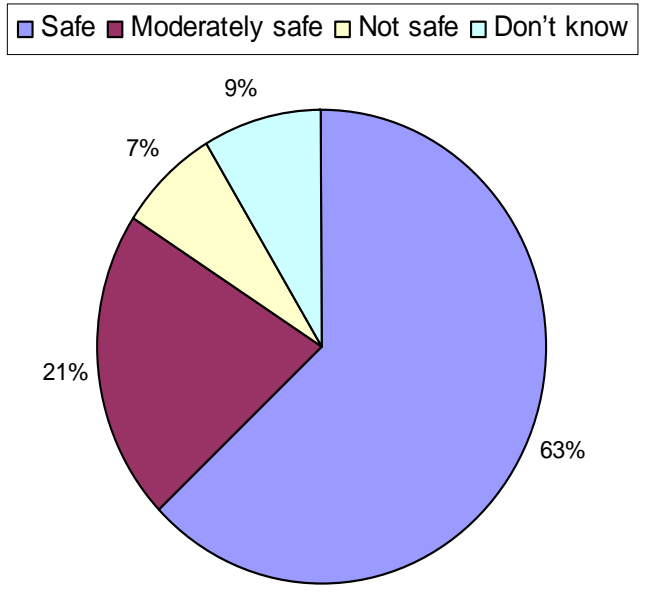

Figure 6 Perception of the respondents to water safeness of the drinking water. 


\section{Satisfaction about the drinking water}

Among all the respondents, about $54.29 \%$ respondents were found to be fully satisfied about their drinking water followed by moderately satisfied $30 \%$ and the rest was found not satisfied $15.71 \%$ (Figure 7). Majority was found satisfied as because they only considered the taste of water, not included other things and beside this, the lack of knowledge about the water related diseases.

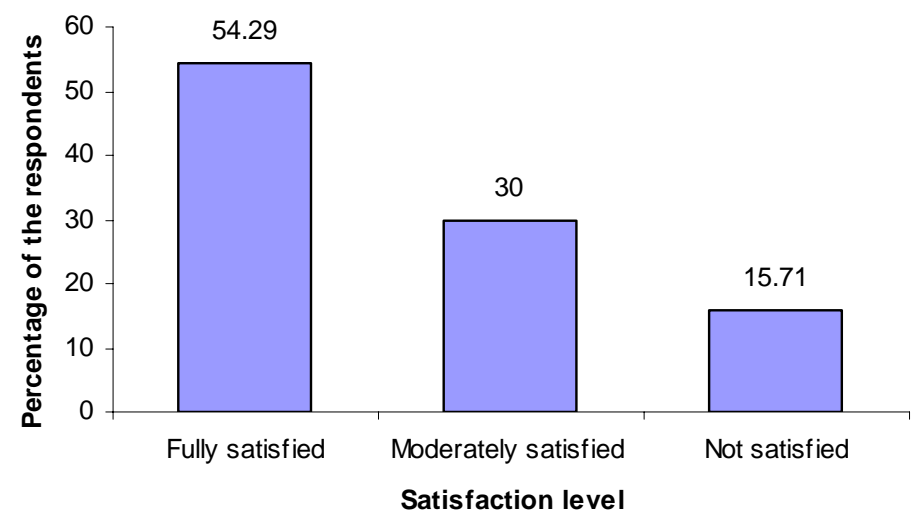

Figure 7 Satisfaction levels of the respondents to drinking water.

\section{Water related problems}

In the study area, some water related problems such as flood, drought, cyclone, salt, iron, arsenic, odor and sand were found as mentioned by the beneficiaries where flood was found to be the major problem as indicated by $71.43 \%$ respondents of beneficiaries followed by iron (35.71\% respondents), and arsenic (28.57\% respondents).

\section{Knowledge and training about water safety plan of the beneficiaries}

About $44.29 \%$ respondents of the beneficiaries was found to have water safety plan about something without training where as $17.14 \%$ respondents was found to have good knowledge for learning training. About $15 \%$ respondents knew only the name of the water safety plan but the rest $22.86 \%$ was found to have no knowledge about water safety plan. In case of training, only NGO was found to provide training to the beneficiaries in all cases as mentioned by the respondents. The result showed that WSP knowledge was very limited among all the beneficiaries as because lack of proper training on the water safety plans after the WSP project implementation.

\section{Communication materials about the water safety plans}

Among all $82.86 \%$ beneficiaries indicated that communication materials were available whereas only $17.14 \%$ respondents said that it was not available. Majority of the communication materials was provided by the NGO as mention by the respondents $(85.71 \%)$. The communication materials were found to be not understandable by most of the respondents $(68.57 \%)$ but $64.29 \%$ respondents mentioned that the available communication materials were sufficient. However, video projection $(85.71 \%)$, bill board $(54.29 \%)$, radio program $(14.29 \%)$, TV $(42.86 \%)$ and pictorial presentation $(40 \%)$ by the respondents suggested as addition to the communication materials (Table 3 ). 
Although the communication materials were available in the project areas but the WSP knowledge was poor. This indicated that communication materials are not easy to understand to the consumer level.

Table 3 Water related issues mentioned by the beneficiaries.

\begin{tabular}{|c|c|c|c|c|}
\hline Characteristics & \multicolumn{2}{|c|}{ Categories (Scores) } & $\begin{array}{l}\text { Number of } \\
\text { respondents }\end{array}$ & Distribution of respondents (\%) \\
\hline \multirow{8}{*}{$\begin{array}{ll}\text { Water } & \text { related } \\
\text { problems } & \end{array}$} & \multicolumn{2}{|l|}{ Flood } & 50 & 71.43 \\
\hline & \multicolumn{2}{|l|}{ Drought } & 6 & 8.57 \\
\hline & \multicolumn{2}{|l|}{ Cyclone } & 5 & 7.14 \\
\hline & \multicolumn{2}{|l|}{ Salt } & 11 & 15.71 \\
\hline & \multicolumn{2}{|l|}{ Iron } & 25 & 35.71 \\
\hline & \multicolumn{2}{|l|}{ Arsenic } & 20 & 28.57 \\
\hline & \multicolumn{2}{|l|}{ Odor } & 22 & 31.43 \\
\hline & \multicolumn{2}{|l|}{ Sand } & 15 & 21.43 \\
\hline \multirow{4}{*}{$\begin{array}{l}\text { Knowledge about } \\
\text { WSP }\end{array}$} & \multicolumn{2}{|l|}{ Nothing/ } & 16 & 22.86 \\
\hline & \multicolumn{2}{|l|}{ Only name } & 11 & 15.71 \\
\hline & \multicolumn{2}{|c|}{ Something without training } & 31 & 44.29 \\
\hline & \multicolumn{2}{|c|}{ Well and trained } & 12 & 17.14 \\
\hline \multicolumn{5}{|c|}{ Training provided by only NGOs in all cases where found } \\
\hline \multirow{15}{*}{$\begin{array}{l}\text { Communication } \\
\text { Materials }\end{array}$} & \multirow[t]{2}{*}{ Availability } & Yes & 58 & 82.86 \\
\hline & & No & 12 & 17.14 \\
\hline & \multirow[t]{3}{*}{ Provided by } & Gov. & 10 & 14.29 \\
\hline & & NGO & 60 & 85.71 \\
\hline & & Others & & \\
\hline & \multirow[t]{2}{*}{ Opinions } & $\begin{array}{l}\text { Understand } \\
\text { properly }\end{array}$ & 22 & 31.43 \\
\hline & & $\begin{array}{l}\text { Can't understand } \\
\text { properly }\end{array}$ & 48 & 68.57 \\
\hline & \multirow[t]{2}{*}{ Sufficiency } & Yes & 45 & 64.29 \\
\hline & & No & 25 & 35.71 \\
\hline & \multirow[t]{6}{*}{ Suggestion } & Video projection & 60 & 85.71 \\
\hline & & Bill board & 38 & 54.29 \\
\hline & & Radio program & 10 & 14.29 \\
\hline & & TV & 30 & 42.86 \\
\hline & & $\begin{array}{l}\text { Pictorial } \\
\text { presentation }\end{array}$ & 28 & 40 \\
\hline & & Others & 20 & 28.57 \\
\hline
\end{tabular}

\section{RISK ASSESSMENT}

\section{Assessment of risk sanitary scoring for the water source site}

The different water sources were categorized for the risk assessment into four categorize low (0-3), Medium (4-6), high (8-6) and very high (9-10). The results showed that $66.66 \%$ deep tube well was in high risk, shallow tube well $57.14 \%$, pond sand filter $50 \%$, rain water harvesting $16.67 \%$, dug well $60 \%$ and pipe water supply $50 \%$ in the same category (figure 9 ). This investigation found majority of 
the rain water harvesting was in high risk (83.33\%) followed by deep tube well (66.67\%). This scoring method might have been influenced by the factors related to the risks of contamination, lack of corrective/management actions, and/or difficulties in controlling the observed hazards at the catchments and/or options sites as suggested by the sanitary inspection forms.

$\square$ Low (0 - 3) $\square$ Medium (4-5) $\square$ High (6-8) $\square$ Very high (9-10)

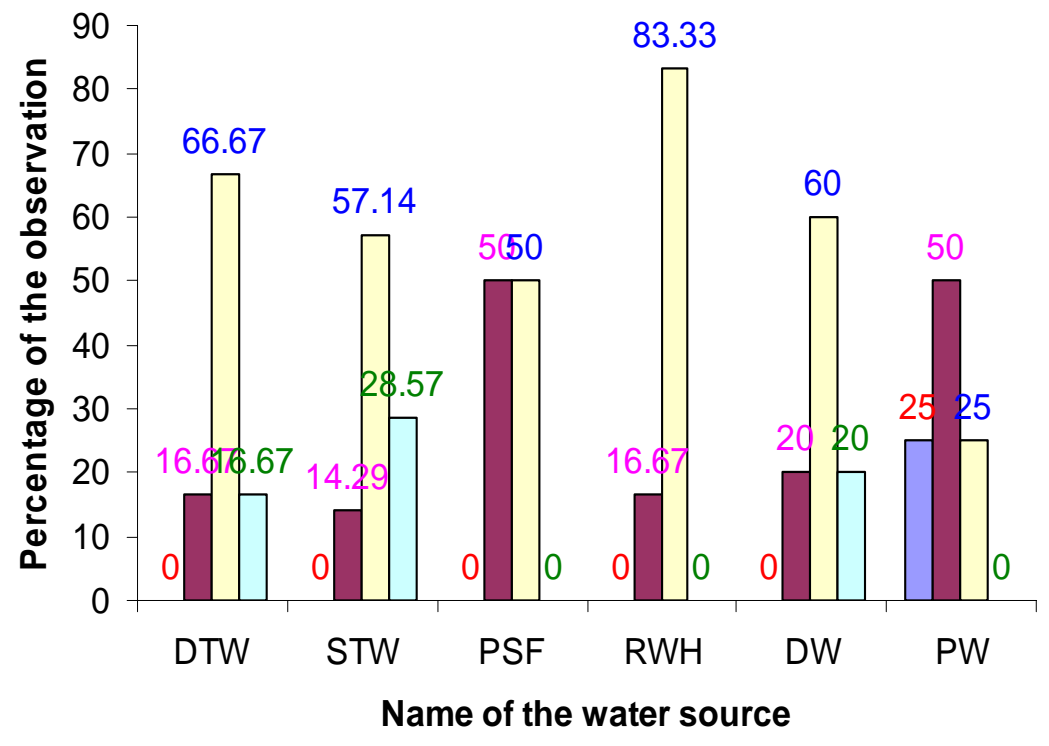

Figure 9 Risk assessments by sanitary scoring for the water source site.

[Note: $\mathrm{DTW}=$ Deep tube well, $\mathrm{STW}=$ Shallow Tube well, $\mathrm{PSF}=$ pond Sand Filter, RWH= Rain Water Harvesting, DW= Dug well, PW= Pipe water]

The sanitary scoring indicated that the drinking water sources specially DTW, STW are in high risk but earlier most of the people said water is safe. This result indicated that the people were not aware about the water safety by the implementation of water safety plans.

\section{Assessment of risk sanitary scoring for the water collection and transportation part}

Water collection and transport is important to assess the risk of water contamination. The result (Table 4 ) clearly showed that the chances of contamination was high in the period of covering the water vessels during storage of water (about 64.71\%) followed by keeping water vessels in safe or high place at home $(55.88 \%)$, contact of cloths with water during transportation $(41.18 \%)$ and use of cover on water vessels during transportation (35.29\%). This result indicated that awareness raising activities by the NGOs was good but the total safety of drinking water was less considered by the WSP project. The study also indicated that the WSP project was failed to achieve the WSP primary goals. 
Table 4 Sanitary scoring for the Water collection and transport part.

\begin{tabular}{|c|c|c|c|c|}
\hline Characteristics & \multicolumn{2}{|l|}{ Categories (Scores) } & Number of & Distribution of \\
\hline \multirow{12}{*}{$\begin{array}{l}\text { Water collection } \\
\text { and transport part }\end{array}$} & \multirow{2}{*}{ Cleaning vessel by soap/ash } & Yes & 13 & 38.24 \\
\hline & & No & 21 & 67.76 \\
\hline & \multirow{2}{*}{$\begin{array}{l}\text { Contact of dirty hand with } \\
\text { collected water }\end{array}$} & Yes & 21 & 61.76 \\
\hline & & No & 13 & 38.24 \\
\hline & \multirow{2}{*}{$\begin{array}{l}\text { Use of cover on vessel at } \\
\text { transportation }\end{array}$} & Yes & 12 & 35.29 \\
\hline & & No & 22 & 64.71 \\
\hline & \multirow{2}{*}{$\begin{array}{l}\text { Contact of cloths with water at } \\
\text { transportation }\end{array}$} & Yes & 14 & 41.18 \\
\hline & & No & 20 & 58.82 \\
\hline & \multirow{2}{*}{$\begin{array}{l}\text { Keeping vessel in safe / high } \\
\text { place at home }\end{array}$} & Yes & 19 & 55.88 \\
\hline & & No & 15 & 44.12 \\
\hline & \multirow{2}{*}{$\begin{array}{l}\text { Covering vessel during } \\
\text { storage of water }\end{array}$} & Yes & 22 & 64.71 \\
\hline & & No & 12 & 35.29 \\
\hline
\end{tabular}

Assessment of risk sanitary scoring for the water storage part

Water storage is so important to assess the risk of water recontamination. The result (Table 5) clearly showed the chance of contamination was very low in the period of handling the water at home $(11.76 \%)$ and about $35.29 \%$ respondents disinfected the water during storage. The investigation showed the needs of disinfection of the drinking water during storage at home.

Table 5. Sanitary scoring for the water storage part.

\begin{tabular}{|c|c|c|c|c|}
\hline Characteristics & \multicolumn{2}{|l|}{ Categories (Scores) } & $\begin{array}{l}\text { Number of } \\
\text { respondents }\end{array}$ & $\begin{array}{ll}\text { Distribution } & \text { of } \\
\text { respondents (\%) }\end{array}$ \\
\hline \multirow{4}{*}{$\begin{array}{l}\text { Water storage } \\
\text { part }\end{array}$} & \multirow{2}{*}{ Contact of hands during use } & Yes & 4 & 11.76 \\
\hline & & No & 30 & 88.24 \\
\hline & \multirow[t]{2}{*}{ Disinfection } & Yes & 12 & 35.29 \\
\hline & & No & 22 & 64.71 \\
\hline
\end{tabular}

\section{Opinion about water safety plans for the official personnel}

\section{Aspects of water safety plans}

Among all the official respondents from both government and NGOs, 45.24\% were not well known about the water safety plans (Table 6). In case of receiving the training on water safety plans, $88.10 \%$ respondents among all the official respondents did not received the water safety plans training (Table 6). This study also found that only NGOs $(100 \%)$ were providing the water safety plans training. Though the percentage of training on water safety plans received was so low but percentage of other water related like water supply and sanitation, water related hygiene practice, etc was high (80.95) (Table 6). 
Table 6 Aspects of water safety plans for the officials.

\begin{tabular}{|c|c|c|c|c|}
\hline Characteristics & \multicolumn{2}{|c|}{ Categories (Scores) } & Number of & Distribution of \\
\hline \multirow{12}{*}{$\begin{array}{l}\text { Water safety } \\
\text { plans }\end{array}$} & \multirow{3}{*}{$\begin{array}{l}\text { Hearing about water safety } \\
\text { plan }\end{array}$} & Yes & 19 & 45.24 \\
\hline & & No & 23 & 54.76 \\
\hline & & Total & 42 & 100 \\
\hline & \multirow[t]{3}{*}{ WSP training received } & Yes & 5 & 11.90 \\
\hline & & No & 37 & 88.10 \\
\hline & & Total & 42 & 100 \\
\hline & \multirow{3}{*}{ Providing organization } & GoB & 0 & 0 \\
\hline & & NGO & 5 & 100 \\
\hline & & Total & 5 & 100 \\
\hline & \multirow[t]{3}{*}{ Other training received } & Yes & 34 & 80.95 \\
\hline & & No & 8 & 19.05 \\
\hline & & Total & 42 & 100 \\
\hline
\end{tabular}

\section{Opinion about the water safety plans monitoring}

In this study, $100 \%$ official respondents were found for conducting the continuous monitoring. The result (Table 7) indicated that $57.14 \%$ monitoring was conducted by the NGOs and the rest $42.86 \%$ was conducted by the government. About 36\% monitoring was done within 15 days interval followed by $33.33 \%$ monthly and $21.43 \%$ half yearly based (Table 7 ). In case of visual monitoring $73.81 \%$ official respondents said yes and the rest said not. In case of water quality test $57.76 \%$ respondent's responded positive and the rest $45.24 \%$ were negative for the lack of laboratory facility (Table 7 ). The most important part of water safety plans monitoring were hygiene monitoring during handling the water specially collection and storage of drinking water but in this section the results showed $78.57 \%$ respondents indicated negative impression (Table 7). 66.67\% officials responded that no sanitary inspection was done.

The study represented that water quality monitoring was not improved after the WSP project implementation

Table 7 Water safety plans monitoring.

\begin{tabular}{|c|c|c|c|c|}
\hline Characteristics & \multicolumn{2}{|c|}{ Categories (Scores) } & $\begin{array}{l}\text { Number of } \\
\text { respondents }\end{array}$ & $\begin{array}{l}\text { Distribution of } \\
\text { respondents (\%) }\end{array}$ \\
\hline \multirow[t]{5}{*}{ Motoring } & \multirow{3}{*}{$\begin{array}{l}\text { Monitoring } \\
\text { being done }\end{array}$} & Yes & 42 & 100 \\
\hline & & No & 0 & 0 \\
\hline & & Total & 42 & 100 \\
\hline & \multirow{2}{*}{$\begin{array}{l}\text { Providing } \\
\text { organization }\end{array}$} & GoB & 18 & 42.86 \\
\hline & & $\mathrm{NGO}$ & 24 & 57.14 \\
\hline
\end{tabular}




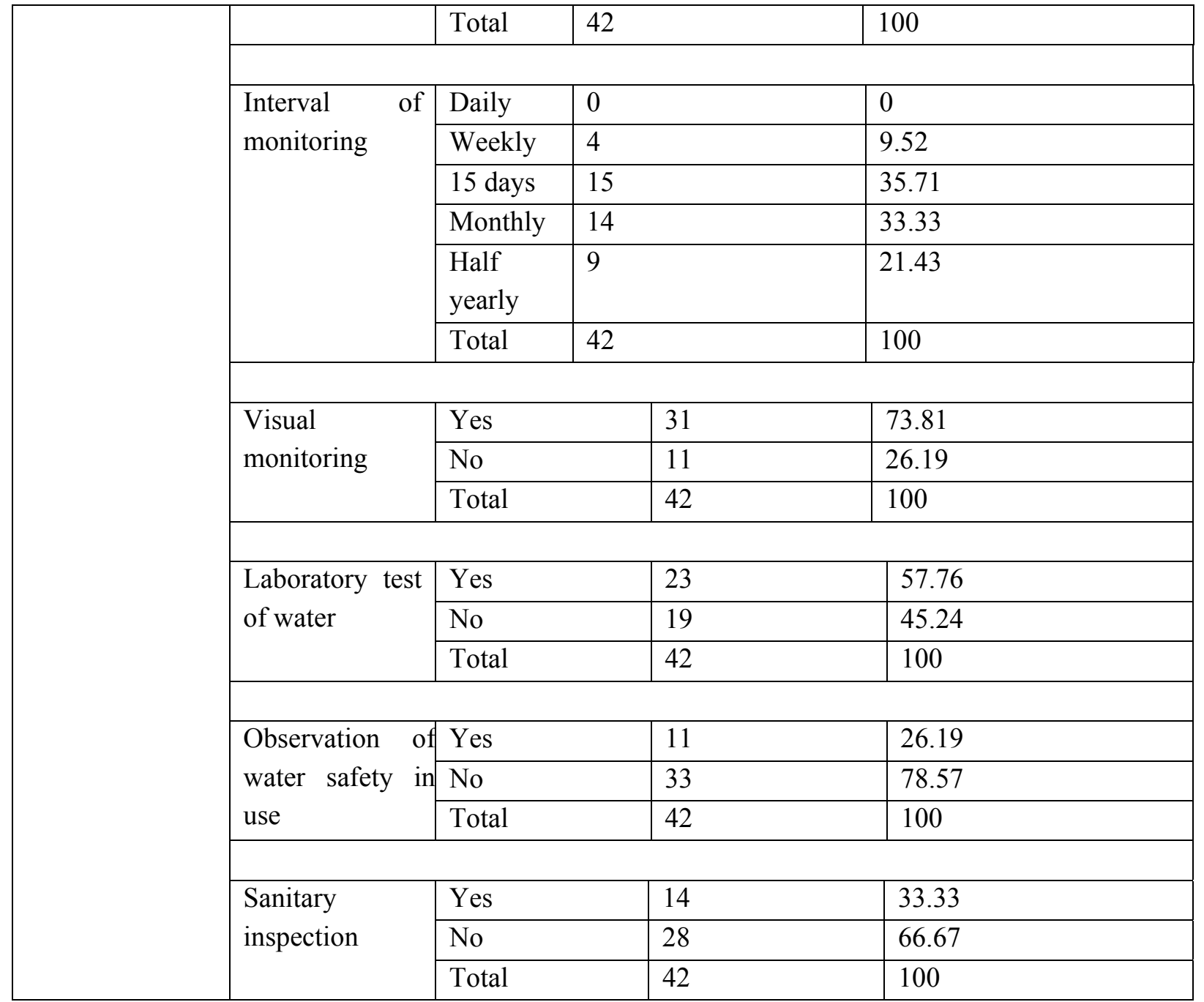

\section{Benefits of water safety plans}

Among all the respondents (112) (both the official and beneficiaries), most of the respondents expressed their agreement about increasing awareness of the people (89 respondents out of 112), decreasing diseases/health hazards (84 respondents out of 112) and increasing water quality (83 respondents out of 112).

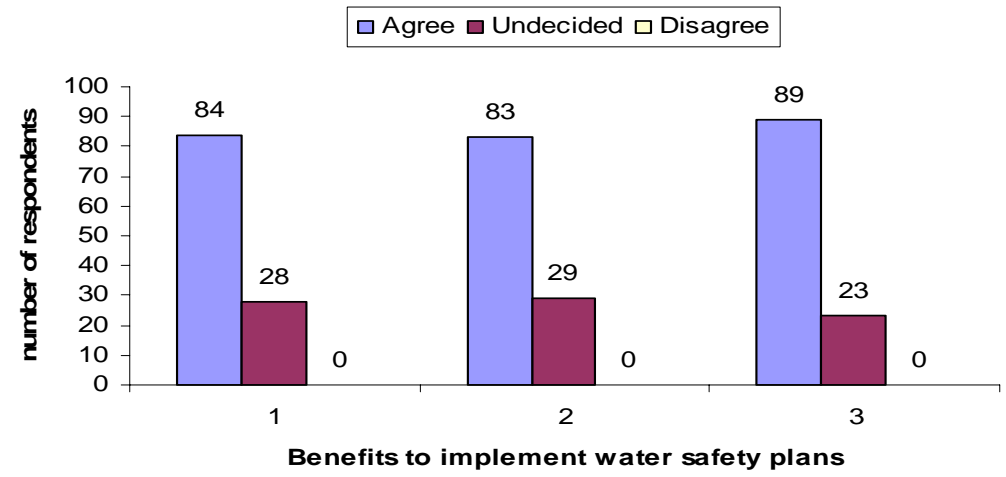

Figure 10 Perception of the respondents according to benefits to implement water safety plans. 
The overall perception scores of the respondents for the benefits were calculated. Based on the obtained score regarding perception, the respondents were classified into three categories. Most of the respondents (78.57\% beneficiaries and $76.19 \%$ organizational personnel) had high perception (Figure 11).

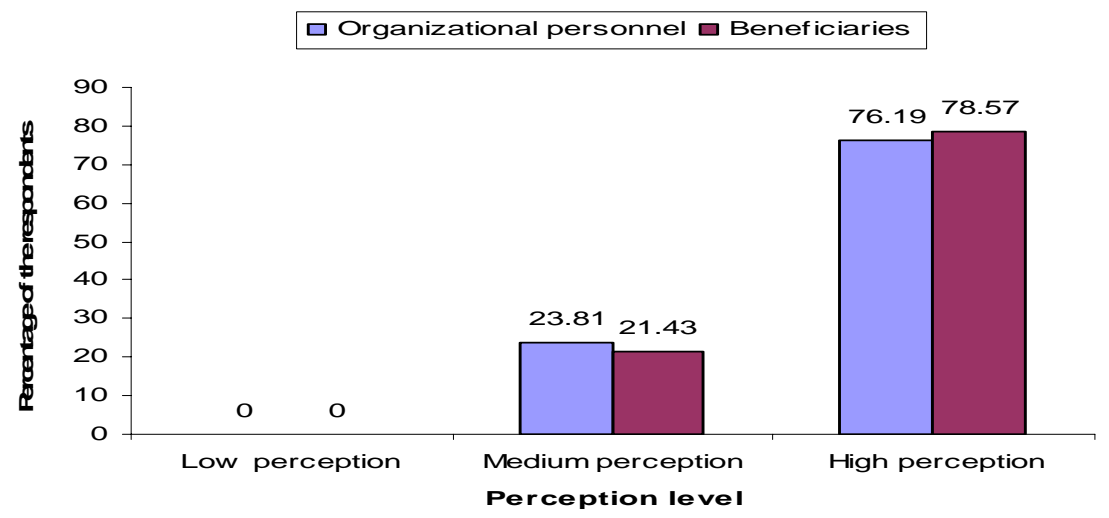

Figure 11 Distribution of the respondents (Both organizational personnel and beneficiaries) according to their perception of benefits of WSP.

\section{Limitations to implement water safety plans}

In the study area, it was clearly found that there were limitations to implement water safety plans as discussed. The respondents' perceptions were tested on the basis of analysis of selected 6 limitations. In this session the respondents' perceptions were analyzed for interpretation and understanding chronologically. Firstly, the distribution of the respondents was done based on their perception against each of the 6 statements i.e., the limitations as well as the overall perception regarding the limitations to implement the water safety plans. Among all the respondents (both the official and beneficiaries), most of the respondents expressed their agreement about Poor economic condition of the people ( 93 respondents out of 112), lack of awareness of the people (89 respondents out of 112), lack of education of the people ( 82 respondents out of 112), lack of Knowledge on WSP ( 80 respondents out of 112), lack of experienced or skilled personnel (79 respondents out of 112) and Lack of laboratory facility (78 respondents out of 112).

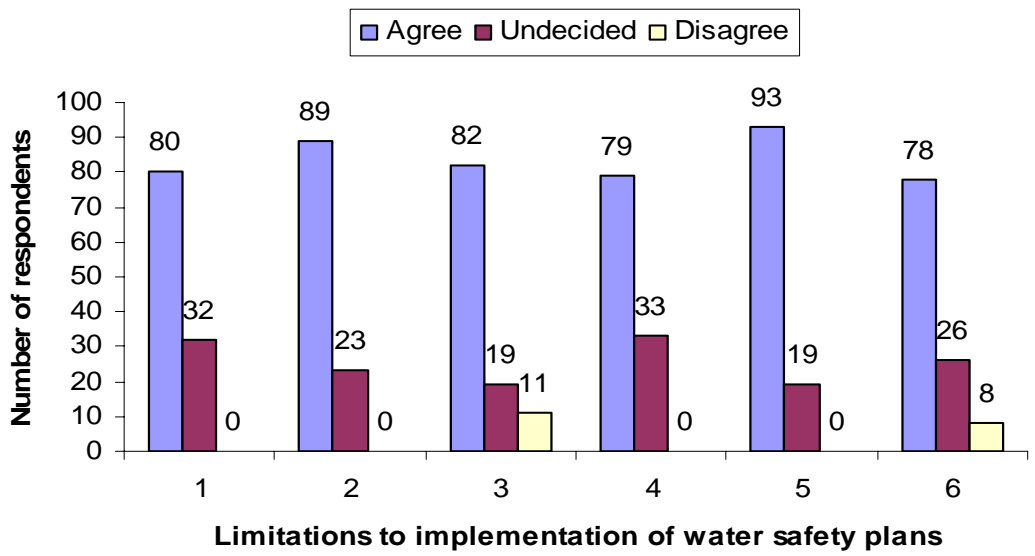

Figure 12 Perception of the respondents according to limitations to implement water safety plans.

[Note: $1=$ Lack of Knowledge on water safety plans, $2=$ lack of awareness of the people, $3=$ Lack of education of the people, $4=$ Lack of experienced or skilled personnel, $5=$ =Poor economic condition of the people, $6=$ Lack of laboratory facility.] 


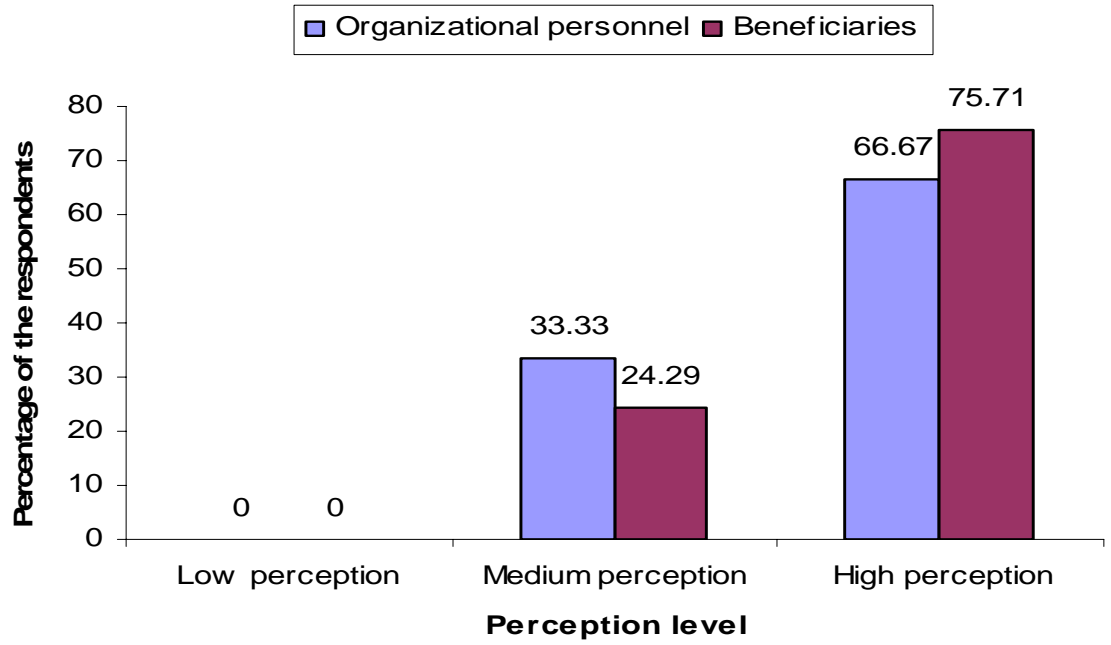

Figure 13 Distribution of the respondents (Both organizational personnel and beneficiaries) according to their perception of limitations of water safety plans.

The overall perception scores of the respondents for the limitations to implement water safety plans were calculated. Based on the obtained score regarding perception, the respondents were classified into three categories. Majority of the respondents $(75.71 \%$ beneficiaries and $66.67 \%$ organizational personnel) had high perception.

\section{Necessities to implement water safety plans}

Among all the respondents (both the official and beneficiaries), most of the respondents expressed their agreement that financial support should be improved ( 102 respondents out of 112), experienced/skilled personnel should be involved (94 respondents out of 112), training program should be increased (87 respondents out of 112), awareness among the root level people should be improved ( 83 respondents out of 112), hygiene education should be increased (81 respondents out of 112 ) and communication materials should be increased (73 respondents out of 112).

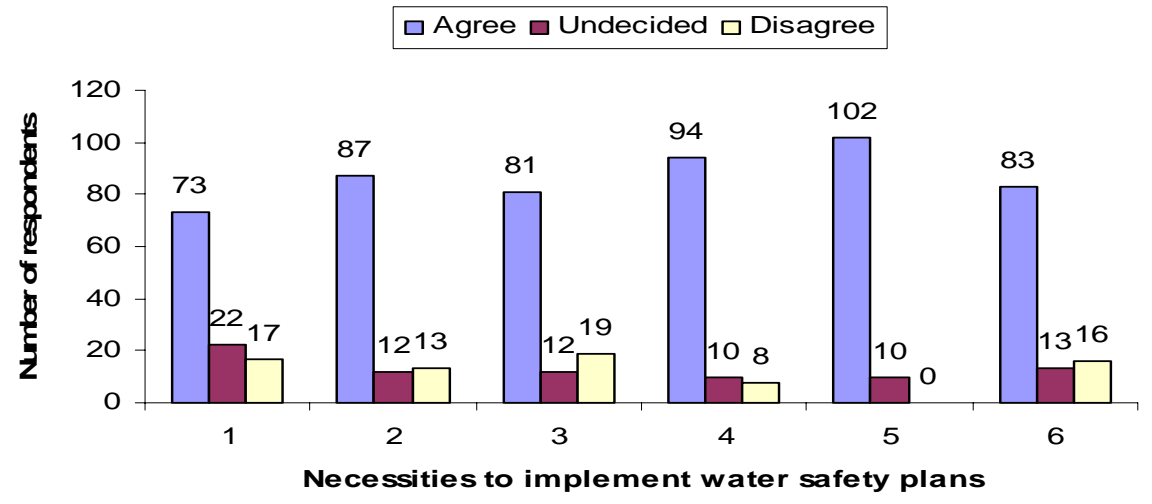

Figure 14 Perception of the respondents according to necessities to implement water safety plans.

[Note: $1=$ Communication materials should be increased, $2=$ Training program should be increased, $3=$ Hygiene education should be increased, 4= Experienced/skilled personnel should be involved, 5= Financial support should be improved, $6=$ Awareness among the root level people should be improved] 


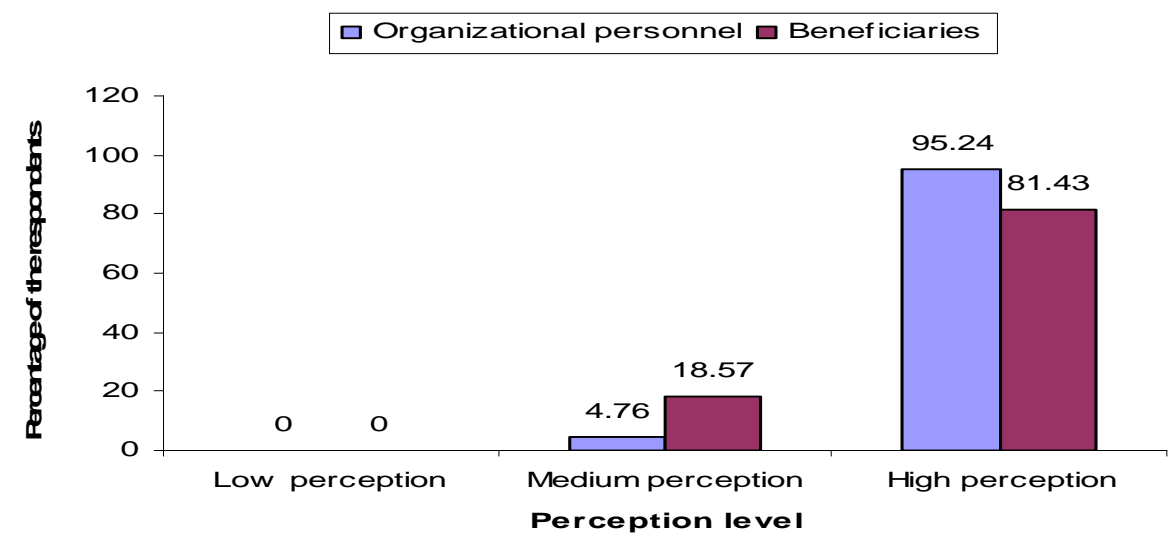

Figure 15. Distribution of the respondents (Both organizational personnel and beneficiaries) according to their perception of needs of WSP.

The overall perception scores of the respondents for the necessities to implement the water safety plans were calculated. Based on the obtained score regarding perception, the respondents were classified into three categories. Majority of the respondents $(95.24 \%$ organizational personnel and $81.43 \%$ beneficiaries) had high perception (Figure 15 ).

\section{CONCLUSION}

The water sector in Bangladesh has made significant efforts to develop and implement water safety plans (WSPs) for rural and urban water supplies. The World Health Organization promotes the use of water safety plans in the 3rd edition of the Guidelines for Drinking Water Quality as a key component of an overall water safety framework. The results of the study had been very positive and the success of a diverse range of organizations in implementing WSPs. The research showed no improvements in the sanitary condition of the water supplies and in microbial water quality. The study also highlighted the need for implementation of WSP and periodic support to communities through surveillance. Community responses were encouraging towards the WSP approach. There was ready acceptance of the community monitoring tools and communities recognized the need for regular monitoring and action. The pictorial tools for community monitoring encouraged the beneficiaries to undertake preventive maintenance and to move sources of hazards, such as pit latrines, to safe distances from the water supply. These actions improved water safety. The existing NGOs can play important roles in the implementation of WSP. In case of drinking water source, it was found that deep tube well and shallow tube well water was used by $31.43 \%$ and $24.29 \%$ respondents respectively where as minority of the respondents use other sources. On the other hand cooking water source found $54.29 \%$ respondents used shallow tube well water and $28.57 \%$ respondents found used pond water. Beside these, $54.29 \%$ of the respondents used the pond water for their bathing purpose. None was found to use pond sand filter and rain water harvesting for their bathing. $60 \%$ of the respondents responded that majority of the water options were established by the NGOs in their area followed by government establishment $30 \%$. About $58.58 \%$ responded that their drinking water source was totally arsenic free where as $30 \%$ responded that they did not know about the arsenic condition. In this study, most of the respondents about $60 \%$ were found to say their water availability was good where as different organization were said it was $69.05 \%$. Flood was found to be the major problem as indicated 
by $71.43 \%$ respondents of beneficiaries. Among all the beneficiaries, $82.86 \%$ beneficiaries were indicated the communication material's availability. This investigation found that $83.33 \%$ rain water harvesting was in high risk followed by deep tube well $66.67 \%$. The result clearly showed that about $64.71 \%$ contamination was occurred in the period of covering the water vessels during storage of water and the chances of contamination was very low in the period of handling the water at home $11.76 \%$. About $35.29 \%$ respondents disinfect the water during storage.In case of receiving the training on water safety plans, $88.10 \%$ respondents among all the official respondents neither received the water safety plans training. Other water related training $(80.95 \%)$ reception percentage well enough like water supply and sanitation, water related hygiene practice, etc. In this study, $100 \%$ official responses were found for conducting the continuous monitoring. About $66.67 \%$ officials were responded that no sanitary inspection was done. Most of the respondents $(78.57 \%$ beneficiaries and $76.19 \%$ organizational personnel) had high perception about the selected three benefits of water safety plans. The result was showed that majority of the respondents $(75.71 \%$ beneficiaries and $66.67 \%$ organizational personnel) had high perception in limitations recognized and majority of the respondents (95.24\% organizational personnel and $81.43 \%$ beneficiaries) had high perception about the necessities to implement water safety plans. Finally, it can be concluded that water safety plans are dynamic by their nature and require regular review and updating. Different water supply projects need to ensure that there is regular interaction and collaboration to support widespread implementation of water safety plans and the development of a water safety framework for Bangladesh.

\section{REFERENCES}

Ahmed. M. F. and Rahman M.M., 2000. Water Supply and Sanitation, ITN- Bangladesh, 444pp.

APSU 2005. Technology water safety plans for rural water supplies in Bangladesh ( $1^{\text {st }}$ edition). www.apsu-bd.org (accessed 2005).

Barry, S.J., Atwill, E.R., Tate, K.W., Koopman, T.S., Cullor, J. and Huff, T. 1998. Developing and implementing a haccp-based programme to control cryptosporidium and other waterborne pathogens in the alameda creek watershed: case study. In AWWA Annual Conference, Texas Water Resources vol. B, pp. 57-69, Dallas.

Davison A, Howard G, Stevens M, Callan P, Kirby R, Deere D, Bartram J. 2005. Water Safety Plans. WHO/SDE/WSH/05.06. World Health Organization, Geneva, Switzerland.

Deere, D. and Davison, A. 1998. Safe water - are food guidelines the answer? Water, 25, 21-24.

Deere, D., Stevens, M., Davison, A., Helm, G. and Dufour, A. 2001. Management Strategies. In Water Quality: Guidelines, standards and health - Assessment of risk and risk management for water-related infectious disease, (eds. J. Bartram and L. Fewtrell), pp. 257-288, WHO, IWA Publishing, London.

Fewtrell, L. and Bartram, J. (eds.) 2001. Water Quality: Guidelines, standards and health-Assessment of risk and risk management for water-related infectious disease. WHO, IWA Publishing, London.

Mahmud, S. G., Shamsuddin, S. A. J., Ahmed, M. F., Davison, A., Deere, D. and Howard, G. 2007. Development and implementation of water safety plans for small water supplies in Bangladesh: benefits and lessons learned. Journal of Water and Health. Vol 5, No 4, pp 585597. at http://www.iwaponline.com/jwh/005/jwh0050585.htm

WHO 2004. Guidelines for Drinking-Water Quality: Recommendations, 3rd edn, vol. 1, WHO,Geneva. 